\title{
PHYSICOCHEMICAL COMPOSITION OF PURE AND ADULTERATED ROYAL JELLY
}

Luis Henrique Garcia-Amoedo e Ligia Bicudo de Almeida-Muradian*

Departamento de Alimentos e Nutrição Experimental, Faculdade de Ciências Farmacêuticas, Universidade de São Paulo, Av. Prof. Lineu Prestes 580, Bloco 14, 05508-900 São Paulo - SP, Brasil

Recebido em 14/3/05; aceito em 5/5/06; publicado na web em 31/10/06

\begin{abstract}
The physicochemical composition of pure royal jelly as well as of some adulterated samples was analyzed by determining moisture, ash, lipids, nitrogen/proteins, carbohydrates, starch and 10- HDA (10-hydroxy-2-decenoic acid). The solubility in alkaline medium was used to detect the main frauds for adulterating royal jelly which comprise addition of yogurt, water, egg white, sweet condensed milk mixed with propolis, unripe banana and corn starch slurry.
\end{abstract}

Keywords: adulteration; royal jelly; beehive products.

\section{INTRODUCTION}

Royal jelly (RJ) is a secretion from the hypofaringeal glands of worker bees which serves as a food for the queen bee and to the growing up larves (from the first to the third day). RJ has a complex composition of proteins, amino acids, sterols, phenols, sugars, minerals and other components and it is hard to obtain it ${ }^{1}$.

In the market, this product has been sold as a food supplement, popularly known to have many nutrients such as carbohydrates, vitamins, minerals and lipids including its characteristic acid (10HDA or 10-hydroxy-2-decenoic acid). Because of the high price of the product, some people can adulterate RJ by adding other products, less expensive, which can not be detected organoleptically like starch corn slurry, yogurt, white of the egg, condensed milk mixed with propolis, unripe banana and water.

Howe $e t a l .^{2}$ analyzed gross composition of fresh samples of RJ and others from commerce using water, protein, lipid, amino acid and fatty acid determination. Commercial samples were compared with fresh samples which were adopted as standards being classified either as authentic or adulterated.

Considering the fact that in 1992 there was not a Brazilian regulation for RJ quality control, Palma ${ }^{3}$, started studying the chemical composition of Brazilian samples of RJ analyzing their moisture, proteins, ash, lipids, carbohydrates and acidity. He concluded that the composition of Brazilian RJ agreed with other values described in literature. However, some differences could be observed, especially in water content that was higher in Brazilian samples.

Bloodworth et al. ${ }^{4}$, knowing the fact that 10 -HDA is the active substance of RJ, and admitting its importance to the quality of RJ, proposed a method for its determination by HPLC. As RJ is the only product that contains 10-HDA naturally, it could be used as an indicator of its authenticity and the presence of $\mathrm{RJ}$ in products in which it was added.

Chen and $\mathrm{Chen}^{5}$ studied some physicochemical changes that occurred in the RJ when it was stored at $-20^{\circ} \mathrm{C}$, at $4{ }^{\circ} \mathrm{C}$ and at room temperature exposed and protected from the light by seven months. The results showed that the viscosity, colour, soluble protein fraction, and the carbohydrates changed significantly when RJ was stored at room temperature; the same did not occur when storage was at $20^{\circ} \mathrm{C}$. The main changes verified were an increment of viscosity,

*e-mail: ligiabi@usp.br browning of the product, and the diminution of carbohydrate content and soluble protein content.

The main purpose of this work is to obtain the physicochemical profile of the RJ adulterated in different proportions of the following adulterants: natural yogurt, pure water, white of the egg, starch corn slurry, a mixture of sweet condensed milk with propolis and unripe banana. This could be useful to detect frauds.

\section{EXPERIMENTAL}

\section{Material}

Seven samples of pure royal jelly obtained directly from beekeepers and from commerce in São Paulo State, Brazil were used. Each sample received a code from A to $\mathrm{G}$ being samples A, B, $\mathrm{D}$ and $\mathrm{G}$ acquired from the market, samples $\mathrm{C}$ and $\mathrm{F}$ were acquired directly from beekeepers and sample $\mathrm{E}$ was declared as Chinese. After the analysis, Sample B was chosen to be adulterated.

All samples were kept frozen $\left(-18^{\circ} \mathrm{C}\right)$ and protected from light, from the receiving time until the analysis procedure.

\section{Preparation of the adulterated samples}

Natural yogurt, pure water, white of the egg, starch corn slurry, a mixture of sweet condensed milk with propolis and unripe banana were added to Sample B in a proportion of 10, 25 and $50 \%(\mathrm{~m} /$ $\mathrm{m})$. The adulteration was prepared in the laboratory, being all the samples kept in the freezer at $-18{ }^{\circ} \mathrm{C}$ and protected from light since the adulteration step until the moment of the analysis.

\section{Standards and solvents}

For the 10-HDA analysis, a reference standard of trans-10hydroxy-2-decenoic acid (acquired from Nippon Shoji Kaisha Ltd. - Chuo-Ku, Osaka, Japan), was used. All solvents used were HPLC grade.

\section{Methods}

\section{Moisture content}

Moisture content was determined by gravimetric analysis using desiccator with sulfuric acid ${ }^{6}$. 
Ash content

Ash content was determined by gravimetry using oven at $550{ }^{\circ} \mathrm{C}^{7}$.

Lipid content

Lipid content was determined by Soxhlet procedure using diethyl ether as solvent ${ }^{7}$.

\section{Total nitrogen and protein content}

The total nitrogen content was obtained using the Micro-Kjeldahl method using the factor of 6.25 for conversion to protein content ${ }^{8}$.

\section{Total carbohydrate}

Total carbohydrate was obtained by difference ${ }^{9}$ using the formula:

Total carbohydrate $=(100 \mathrm{~g}-\mathrm{g}$ of moisture, protein, lipids and ash $)$.

\section{Starch/ iodine reaction}

To identify the presence or absence of starch in the samples, the iodine reaction ${ }^{10}$ was used. $1.5 \mathrm{~g}$ of the sample was weighed, diluted in $20 \mathrm{~mL}$ of distilled water and the solution was heated till boil and then lowed the temperature to cold. Three drops of the iodine solution were added. A standard with pure starch was prepared for a positive control for comparison data.

\section{Alkaline solubility}

The water solubility of the samples was tested using $1.0 \mathrm{~g}$ of the sample, diluted to $20 \mathrm{~mL}$ with distilled water resulting in a characteristic turbidity. $\mathrm{NaOH}$ solution $(20 \%)$ was added, drop to drop, from the pipette till complete solubilization of the sample ${ }^{10}$.

\section{HPLC determination of trans-10-hydroxy- 2-decenoic acid (10-HDA)}

The 10-HDA determination was similar to that used by GarciaAmoedo and Almeida-Muradian ${ }^{11}$, Koshio and Almeida-Muradian ${ }^{12}$ and Pamplona et al. ${ }^{13}$. High Performance Liquid Chromatography (HPLC) was used under the following conditions: an isocratic system with a Shimadzu ${ }^{\circledR}$ LC9A pump, an auto sampler and a diode array detector (Shimadzu ${ }^{\oplus}$ SPD-MXA). The column used was a reversed phase column $\mathrm{C}_{18}-\mathrm{H}\left(\right.$ Shimadzu $^{\oplus}, 150$ x $4.0 \mathrm{~mm}$ x $\left.5 \mu \mathrm{m}\right)$. The mobile phase was composed by methanol/water (45:55); the $\mathrm{pH}$ was adjusted to 2.5 with phosphoric acid, filtered through $0.45 \mu \mathrm{m}$ membrane (Millipore $^{\circledR}$ ) and degassed during $5 \mathrm{~min}$ with helium gas. The flow rate was $0.5 \mathrm{~mL} /$ minute. The detector was adjusted to $225 \mathrm{~nm}$. The running time for analysis was $30 \mathrm{~min}$. It was used $\alpha$-naphtol as internal standard. Data were obtained using the software SPD-MXA $\left(\right.$ Shimadzu $\left.^{\circledR}\right)$ which is part of the chromatographic system.

A standard curve was constructed with 5 points of concentrations: $2.73,5.46,10.92,16.38$ and $21.84 \mu \mathrm{g} / \mathrm{mL}$ of $10-$ HDA, adding $\alpha$-naphtol solution to obtain a final concentration of $30 \mu \mathrm{g} / \mathrm{mL}$ in mobile phase, filtered through $0.22 \mu \mathrm{m}$ membrane (Millipore $^{\circledR}$ ), and $5 \mu \mathrm{L}$ were injected in the chromatographic system.

$30 \mathrm{mg}$ of RJ was weighed in a volumetric flask of $10 \mathrm{~mL} ; 1 \mathrm{~mL}$ of $\alpha$-naphtol solution (with concentration of $30 \mu \mathrm{g} / \mathrm{mL}$ ) was added, and the volume was completed with mobile phase. The solution was filtered through a $0.22 \mu \mathrm{m}$ membrane, and $5 \mu \mathrm{L}$ were injected into the chromatographic system.

\section{RESULTS AND DISCUSSION}

The results for pure royal jelly samples are presented on Table 1 for the proximate analysis and on Table 2 for 10-HDA content.

The results of comparison of all physicochemical analysis of
Table 1. Proximate analysis of seven samples of pure royal jelly

\begin{tabular}{|c|c|c|c|c|c|}
\hline \multirow[t]{2}{*}{ Samples } & \multicolumn{4}{|c|}{ Determinations $(\%)^{*}$} & \multirow{2}{*}{$\begin{array}{l}\text { Obtained from } \\
\text { calculation }(\%) \\
\text { Carbohydrates }\end{array}$} \\
\hline & Moisture & Ash & Lipids & Proteins & \\
\hline A & 61.45 & 1.17 & 2.17 & 14.01 & 21.20 \\
\hline B & 67.58 & 0.93 & 4.20 & 11.99 & 15.30 \\
\hline $\mathrm{C}$ & 63.44 & 0.97 & 4.22 & 12.42 & 18.95 \\
\hline D & 61.50 & 1.11 & 3.25 & 13.63 & 20.51 \\
\hline $\mathrm{E}$ & 63.76 & 1.06 & 2.86 & 13.28 & 19.04 \\
\hline $\mathrm{F}$ & 62.33 & 1.11 & 3.90 & 13.26 & 19.40 \\
\hline G & 62.14 & 1.08 & 2.38 & 13.25 & 21.15 \\
\hline Means & 63.17 & 1.06 & 3.28 & 13.12 & 19.36 \\
\hline $\operatorname{RSD}(\%)$ & 1.98 & 0.08 & 0.78 & 0.64 & 1.88 \\
\hline
\end{tabular}

* means of three replications; RSD $=$ relative standard deviations

Table 2. 10-HDA content of the seven samples of pure royal jelly

\begin{tabular}{lcc}
\hline Samples & 10-HDA*(means) & RSD $(\%)$ \\
\hline A & 1.58 & 0.10 \\
B & 3.17 & 0.23 \\
C & 3.39 & 0.37 \\
D & 2.70 & 0.30 \\
E & 1.98 & 0.12 \\
F & 3.10 & 0.14 \\
G & 1.82 & 0.28 \\
\hline
\end{tabular}

*means of three replications; (HPLC analysis using internal standard and calibration curves)

Table 3. Proximate analysis and 10-HDA data from regular and adulterated royal jelly samples (in percentage)

\begin{tabular}{lcccccc}
\hline \multirow{2}{*}{ Samples } & \multicolumn{6}{c}{ Determinations (\%)* } \\
& Moisture & Ash & Lipids & Proteins & $\begin{array}{c}\text { Carbo- } \\
\text { hydrate }\end{array}$ & HDA \\
\hline Pure Royal & 67.58 & 0.93 & 4.20 & 11.99 & 15.30 & 3.17 \\
Jelly & & & & & & \\
(sample B) & & & & & & \\
10\% CM & 59.96 & 0.90 & 4.67 & 12.21 & 22.26 & 2.88 \\
25\% CM & 52.96 & 1.01 & 5.25 & 11.08 & 29.7 & 2.44 \\
50\% CM & 40.70 & 1.89 & 6.31 & 9.83 & 41.27 & 1.63 \\
10\% Yogurt & 67.87 & 0.85 & 3.92 & 11.16 & 16.20 & 2.75 \\
25\% Yogurt & 70.07 & 0.74 & 3.43 & 9.98 & 15.15 & 2.51 \\
50\% Yogurt & 75.11 & 0.67 & 2.70 & 7.65 & 13.87 & 0.96 \\
10\% WE & 66.74 & 0.84 & 3.65 & 12.12 & 16.65 & 2.80 \\
25\% WE & 70.21 & 0.74 & 3.12 & 11.76 & 14.17 & 2.48 \\
50\% WE & 76.16 & 0.66 & 2.21 & 11.45 & 9.52 & 1.47 \\
10\% Water & 69.01 & 0.81 & 3.70 & 11.24 & 15.24 & 2.83 \\
25\% Water & 73.99 & 0.66 & 2.98 & 9.21 & 13.16 & 2.47 \\
50\% Water & 81.95 & 0.48 & 2.25 & 6.30 & 9.02 & 1.42 \\
10\% Starch & 67.43 & 0.85 & 3.73 & 11.44 & 16.55 & 2.81 \\
25\% Starch & 72.69 & 0.61 & 3.09 & 9.22 & 14.39 & 2.48 \\
50\% Starch & 79.57 & 0.42 & 2.18 & 6.52 & 11.31 & 1.41 \\
\hline
\end{tabular}

* means of two replications, $\mathrm{CM}=$ condensed milk, $\mathrm{WE}=$ white of the egg

pure and adulterated samples are presented on Table 3.

As the adulteration of RJ was not possible with unripe banana because of changes in some organoleptic characteristics like flavor (typical from banana) and colour (dark), this kind of adulteration was not used for the physicochemical analysis. 
Solubility test showed that all the pure samples and the one adulterated with water became soluble in alkaline medium. All the other adulterated samples showed some degree of turbidity in alkaline medium, depending on the kind and the percentage of each adulterant. Samples adulterated with yogurt and white of the egg showed higher turbidity compared with the samples adulterated with starch. This analysis can be useful for a previous trial for adulteration check.

10-HDA content decreased when adulterants were added, having the minimum of 0.96 when $50 \%$ of yogurt was added.

\section{CONCLUSIONS}

Adulterations in RJ can be detected by interaction of the solubility test in alkaline medium with determinations of proximate analysis, 10-HDA content, and iodine-starch reaction. The main changes in physicochemical properties of adulterated samples were: samples adulterated with yogurt, white of the egg, water and starch corn slurry, in concentrations higher than $25 \%$, can be detected by the enhancement of moisture, diminishing in lipid, protein and 10HDA content, and insolubility in alkaline medium; samples adulterated with yogurt, white of the egg, water and starch corn slurry, in concentrations near $10 \%$ can be detected by a little enhancement in moisture, and a diminishing of lipid, protein and 10-HDA content and insolubility in alkaline medium; samples adulterated with condensed milk in concentrations higher than $10 \%$ can be detected by an enhancement of lipid content and a diminishing of moisture, protein and 10-HDA; the absence of 10HDA showed a total substitution of royal RJ.

\section{REFERENCES}

1. Krell, R.; FAO Agricultural Services Bulletin, No. 124, Rome, 1996.

2. Howe, S. R.; Dimick, P. S.; Benton, A. W.; J. Apic. Res. 1985, 24, 52.

3. Palma, M. S.; J. Apic. Res. 1992, 31, 42.

4. Bloodworth, B. C.; Harn, C. S.; Hock, C. T.; Boon, Y. O.; J. AOAC Int. 1995, 78, 1019.

5. Chen, C.; Chen, S. Y.; Food Chem. 1995, 54, 195.

6. Garcia-Amoedo, L. H.; Almeida-Muradian, L. B.; Quim. Nova 2002, 25, 676.

7. Instituto Adolfo Lutz; Normas analíticas do Instituto Adolfo Lutz, $3^{\mathrm{a}}$ ed., Instituto Adolfo Lutz: São Paulo, 1985.

8. Association of Official Analytical Chemists; Official methods of analysis, $14^{\text {th }}$ ed., AOAC: Arlington, 1984.

9. http://www.fcf.usp.br/tabela/, acessada em Maio 2006.

10. Garcia-Amoedo, L. H.; Dissertação de Mestrado, Universidade de São Paulo, Brasil, 1999.

11. Garcia-Amoedo, L. H.; Almeida-Muradian, L. B.; Ciência e Tecnologia de Alimentos 2003, 23, 62 .

12. Koshio, S.; Almeida-Muradian, L. B.; Quim. Nova 2003, 26, 670.

13. Pamplona, L. C.; Azedo, R. A. B.; Oliveira, K.; Garcia-Amoedo, L. H.; Almeida-Muradian, L. B.; Ciência e Tecnologia de Alimentos 2004, 24, 608. 